\title{
Aerosol hygroscopicity derived from size-segregated chemical composition and its parameterization in the North China Plain
}

\author{
H. J. Liu ${ }^{1}$, C. S. Zhao ${ }^{1}$, B. Nekat ${ }^{2}$, N. Ma1 ${ }^{1}$, A. Wiedensohler ${ }^{2}$, D. van Pinxteren ${ }^{2}$, G. Spindler ${ }^{2}$, K. Müller ${ }^{2}$, and \\ H. Herrmann ${ }^{2}$ \\ ${ }^{1}$ Department of Atmospheric and Oceanic Sciences, School of Physics, Peking University, Beijing 100871, China \\ ${ }^{2}$ Leibniz-Institute for Tropospheric Research, TROPOS, 04318 Leipzig, Germany
}

Correspondence to: C. S. Zhao (zcs@pku.edu.cn)

Received: 17 July 2013 - Published in Atmos. Chem. Phys. Discuss.: 12 August 2013

Revised: 20 January 2014 - Accepted: 6 February 2014 - Published: 12 March 2014

\begin{abstract}
Hygroscopic growth of aerosol particles is of significant importance in quantifying the aerosol radiative effect in the atmosphere. In this study, hygroscopic properties of ambient particles are investigated based on particle chemical composition at a suburban site in the North China Plain during the HaChi campaign (Haze in China) in summer 2009. The size-segregated aerosol particulate mass concentration as well as the particle components such as inorganic ions, organic carbon and water-soluble organic carbon (WSOC) are identified from aerosol particle samples collected with a ten-stage impactor. An iterative algorithm is developed to evaluate the hygroscopicity parameter $\kappa$ from the measured chemical composition of particles. During the HaChi summer campaign, almost half of the mass concentration of particles between $150 \mathrm{~nm}$ and $1 \mu \mathrm{m}$ is contributed by inorganic species. Organic matter $(\mathrm{OM})$ is abundant in ultrafine particles, and $77 \%$ of the particulate mass with diameter $\left(D_{\mathrm{p}}\right)$ of around $30 \mathrm{~nm}$ is composed of OM. A large fraction of coarse particle mass is undetermined and is assumed to be insoluble mineral dust and liquid water. The campaign's average size distribution of $\kappa$ values shows three distinct modes: a less hygroscopic mode $\left(D_{\mathrm{p}}<150 \mathrm{~nm}\right)$ with $\kappa$ slightly above 0.2 , a highly hygroscopic mode $\left(150 \mathrm{~nm}<D_{\mathrm{p}}<1 \mu \mathrm{m}\right)$ with $\kappa$ greater than 0.3 and a nearly hydrophobic mode $\left(D_{\mathrm{p}}>1 \mu \mathrm{m}\right)$ with $\kappa$ of about 0.1 . The peak of the $\kappa$ curve appears around $450 \mathrm{~nm}$ with a maximum value of 0.35 . The derived $\kappa$ values are consistent with results measured with a high humidity tandem differential mobility analyzer within the size range of 50-250 nm. Inorganics are the predominant species contributing to particle hygroscopicity, especially for particles between $150 \mathrm{~nm}$ and $1 \mu \mathrm{m}$. For example, $\mathrm{NH}_{4} \mathrm{NO}_{3}, \mathrm{H}_{2} \mathrm{SO}_{4}$,
\end{abstract}

$\mathrm{NH}_{4} \mathrm{HSO}_{4}$ and $\left(\mathrm{NH}_{4}\right)_{2} \mathrm{SO}_{4}$ account for nearly $90 \%$ of $\kappa$ for particles of around $900 \mathrm{~nm}$. For ultrafine particles, WSOC plays a critical role in particle hygroscopicity due to the predominant mass fraction of OM in ultrafine particles. WSOC for particles of around $30 \mathrm{~nm}$ contribute $52 \%$ of $\kappa$. Aerosol hygroscopicity is related to synoptic transport patterns. When southerly wind dominates, particles are more hygroscopic; when northerly wind dominates, particles are less hygroscopic. Aerosol hygroscopicity also has a diurnal variation, which can be explained by the diurnal evolution of planetary boundary layer, photochemical aging processes during daytime and enhanced black carbon emission at night. $\kappa$ is highly correlated with mass fractions of $\mathrm{SO}_{4}{ }^{2-}, \mathrm{NO}_{3}{ }^{-}$and $\mathrm{NH}_{4}{ }^{+}$for all sampled particles as well as with the mass fraction of WSOC for particles of less than $100 \mathrm{~nm}$. A parameterization scheme for $\kappa$ is developed using mass fractions of $\mathrm{SO}_{4}{ }^{2-}, \mathrm{NO}_{3}{ }^{-}, \mathrm{NH}_{4}{ }^{+}$and WSOC due to their high correlations with $\kappa$, and $\kappa$ calculated from the parameterization agrees well with $\kappa$ derived from the particle's chemical composition. Further analysis shows that the parameterization scheme is applicable to other aerosol studies in China.

\section{Introduction}

Hygroscopicity, as one of the most important characteristics of aerosol particles, influences the magnitude of aerosol radiative effect. Aerosol particles are modeled to have a cooling effect on a global scale $\left(-1.2 \mathrm{~W} \mathrm{~m}^{-2}\right)$ with large uncertainty $\left(+0.8 /-1.5 \mathrm{~W} \mathrm{~m}^{-2}\right)$, and the incomplete knowledge of particle hygroscopic growth is considered to be one of the 
main sources of the uncertainty (IPCC, 2007). When exposed to high relative humidity (RH) conditions, particles grow by absorbing water and their scattering cross sections are enhanced. In supersaturated conditions, the particle hygroscopicity as a function of diameter determines the ability to activate as cloud droplets, and further influences the cloud's microphysical properties (Zhao et al., 2006a) and precipitation probability of clouds (Zhao et al., 2006b). Beside its influence on radiative transfer, hygroscopicity is also relevant to aqueous phase reactions in the atmosphere where the condensed water serves as the reaction medium. Moreover, the hygroscopic growth of particles exposed to high relative humidity conditions can substantially decrease visibility (Chen et al., 2012).

Hygroscopicity can be characterized by the hygroscopic growth factor (HGF), which is defined as the ratio of the diameter of the wet particle at a certain relative humidity to the corresponding diameter at dry conditions. Hygroscopic tandem differential mobility analyzer (H-TDMA) instruments have been used globally to determine HGFs of ambient size-resolved aerosols (Swietlicki et al., 2008). Swietlicki et al. (2008) have reported that HGF values are reliable with an uncertainty of \pm 0.05 , confirming that measurements by H-TDMAs are of high accuracy. However, due to technical limitations, H-TDMAs can only measure dry particles smaller than $300 \mathrm{~nm}$, while the contribution of dry particles of between 300 and $600 \mathrm{~nm}$ to the total particle scattering is significant. In order to achieve comprehensive understanding of the hygroscopic growth behavior of aerosols, other techniques should be introduced.

Hygroscopicity can also be predicted from chemical composition that determines the ability of a particle to take up water (Gysel et al., 2007). The earliest attempt described a particle as an insoluble core coated with an assumed inorganic salt (Junge and McLaren, 1971). In later studies (Saxena et al., 1995; Gysel et al., 2004), organic matter was confirmed to contribute to the overall absorbed water of atmospheric particles and was involved in the models. Several studies (Shulman et al., 1996; Laaksonen et al., 1998) proposed extended theories based on Köhler's theory to describe particle hygroscopic growth and the activation process to cloud droplets. However, the application of these extended theories requires detailed properties, such as molecular weights, bulk densities and water activity coefficients, which are unavailable for ambient aerosols containing a multitude of generally unidentified organic compounds. Petters and Kreidenweis (2007) proposed a single-parameter scheme to simplify Köhler's theory. In this theory, all chemistry-depended values are merged into a single parameter $\kappa$ representing a quantitative measure of aerosol hygroscopicity.

As one of the most polluted regions in the world, the North China Plain (NCP) suffers from heavy aerosol loading, which is the byproduct of the rapid economic growth and urbanization (Liu et al., 2009). The NCP is under the impact of the Asian monsoon, so water vapor supply is abun- dant during summer. Also, haze and fog frequently occur and cause severe low-visibility events (Quan et al., 2011). Therefore, studies on aerosol hygroscopic properties in the NCP are necessary. In the studies by Pan et al. (2009) and Yan et al. (2009), the influence of aerosol hygroscopic growth on scattering coefficients was investigated with a humidified nephelometer system at both urban and rural sites in Beijing and a comparative analysis of the aerosol's scattering enhancement was conducted. A high humidity tandem differential mobility analyzer (HH-TDMA) instrument was used in the HaChi (Haze in China) summer campaign to measure HGFs at RHs of up to $98.5 \%$ (Liu et al., 2011). Moreover, there were several studies that determined particle hygroscopicity based on aerosol chemical properties (Massling et al., 2009; Meier et al., 2009).

In this study, we evaluate aerosol hygroscopicity from size-segregated chemical composition analysis of ambient particles. An iterative algorithm is set up based on the $\kappa$ Köhler theory to predict the hygroscopicity parameter $\kappa$. A parameterization scheme is proposed to predict the hygroscopicity parameter $\kappa$ from the particle chemical composition. Furthermore, data sets from other aerosol field campaigns are introduced to test the generality of this parameterization scheme.

\section{Experimental}

\subsection{Campaign}

As a collaborative project of Peking University, China, and the Leibniz Institute for Tropospheric Research (LIfT), Germany, the HaChi campaign was conducted at the Wuqing Meteorological Station $\left(39^{\circ} 23^{\prime} \mathrm{N}, 117^{\circ} 01^{\prime} \mathrm{E}, 7.4 \mathrm{~m}\right.$ a.s.l.) in Wuqing, Tianjin, in summer 2009. Wuqing is a suburban district located between the two megacities of Beijing (about $80 \mathrm{~km}$ away in the northwest) and Tianjin (about $30 \mathrm{~km}$ away in the southeast). Yanshan Mountain is located at the north edge of the NCP and is about $100 \mathrm{~km}$ away from Wuqing. Beyond the mountain is the Inner Mongolia Plateau, which is sparsely populated. The distribution of the $4 \mathrm{yr}$ (20052008) average aerosol optical depth (AOD) derived from the Moderate Resolution Imaging Spectroradiometer (MODIS) at $550 \mathrm{~nm}$ wavelength shows that the area of AOD exceeding 0.6 spreads in the NCP, while urban areas such as Beijing and Tianjin are the severely polluted regions with AOD exceeding 0.8. Wuqing is located in the area with a $4 \mathrm{yr}$ AOD between 0.6 and 0.8 , representing the regional background of the NCP and thus, is an optimal measurement site (Liu et al., 2011). The landscape around the measurement site has been described in detail by Ran et al. (2011).

During the field campaign, particle number size distributions, optical properties such as particle light scattering and absorption coefficients, hygroscopic growth factors and CCN (cloud condensation nuclei) activation ratios were measured 
Table 1. Size ranges of the ten-stage Berner low pressure impactor. The lower and upper limits of each stage represent the $50 \%$ cutoff aerodynamic diameters.

\begin{tabular}{rrrrr}
\hline $\begin{array}{r}\text { Impactor } \\
\text { stage }\end{array}$ & $\begin{array}{r}\text { Lower } \\
\text { limit }(\mu \mathrm{m})\end{array}$ & $\begin{array}{r}\text { Upper } \\
\text { limit }(\mu \mathrm{m})\end{array}$ & $\begin{array}{r}\text { Geometric } \\
\text { mean diameter } \\
\text { a } \\
(\mu \mathrm{m})\end{array}$ & $\begin{array}{r}\text { Volume } \\
\text { equivalent dry } \\
\text { diameter }^{\mathrm{b}}(\mu \mathrm{m})\end{array}$ \\
\hline 1 & 0.015 & 0.03 & 0.021 & - \\
2 & 0.03 & 0.06 & 0.042 & 0.030 \\
3 & 0.06 & 0.125 & 0.086 & 0.061 \\
4 & 0.125 & 0.25 & 0.176 & 0.122 \\
5 & 0.25 & 0.5 & 0.353 & 0.235 \\
6 & 0.5 & 1 & 0.707 & 0.458 \\
7 & 1 & 2 & 1.41 & 0.917 \\
8 & 2 & 4 & 2.82 & 1.98 \\
9 & 4 & 8 & 5.65 & 4.01 \\
10 & 8 & 16 & 11.31 & - \\
\hline
\end{tabular}

a The geometric mean diameter of each impactor stage is the square root of the product of the lower limit multiplied with the corresponding upper limit. ${ }^{b}$ The campaign's average volume equivalent diameter of dry particles are evaluated from the iterative algorithm in Sect. 3.3.

at the ground level. Parallel size-resolved aerosol sampling was carried out with a ten-stage Berner low pressure impactor (BLPI; Hillamo and Kauppinen, 1991) from 14 July to 14 August 2009. The particle size ranges and mean diameters for the individual impactor stages are given in Table 1 . The aerosol sampling took place twice a day, with each sampling lasting for $6 \mathrm{~h}$ from 11:00 to 17:00 local time (+08:00 GMT) during daytime and from 20:00 to 02:00 local time during nighttime. The impactor samples were carefully stored at about $-20^{\circ} \mathrm{C}$ for further analysis.

\subsection{Data}

The determination of the particulate mass concentration and the chemical characterization of the impactor samples were done by the chemistry department of the LIfT, Germany. Before analysis, the impactor sample substrates were equilibrated for at least $48 \mathrm{~h}$ under constant conditions with RH of $52 \%$ and temperature of $20^{\circ} \mathrm{C}$. Size-segregated mass concentration was determined gravimetrically by weighing the sample substrates before and after sampling using a microbalance UMT-2 (Mettler Toledo, Switzerland) with reading precision of $0.1 \mu \mathrm{g}$ and standard deviation of $1 \%$. The uncertainty related to mass loss during sampling, shipment and storage was estimated at about $5 \%$ at the $99 \%$ confidence level (Cheng et al., 2008).

After weighing, the sample substrates were cut into pieces for the chemical characterization. Analyzed chemical species included inorganic ions $\left(\mathrm{NH}_{4}^{+}, \mathrm{Na}^{+}, \mathrm{K}^{+}, \mathrm{Mg}^{2+}, \mathrm{Ca}^{2+}\right.$, $\mathrm{NO}_{3}{ }^{-}, \mathrm{SO}_{4}{ }^{2-}, \mathrm{Cl}^{-}$), elemental carbon (EC), organic carbon (OC), water-soluble organic carbon (WSOC) and some other species such as dicarboxylic acids. The analytical methods for these chemical components were described by van Pinxteren et al. (2009) in detail. The uncertainty was estimated at about $5 \%$ at the $99 \%$ confidence level (Cheng et al., 2008).
Chemical data were presented and analyzed only for particles in impactor stages $2-9(30 \mathrm{~nm}-4 \mu \mathrm{m})$, because the mass concentrations in stage 1 were generally below the detection limit.

An HH-TDMA system (Hennig et al., 2005) was used to measure size-resolved hygroscopic properties of aerosols at high RH conditions. During the HaChi summer campaign, the selected dry diameters were 50,100, 200 and $250 \mathrm{~nm}$ and the RHs were 90,95 and $98.5 \%$. The system was calibrated daily with pure ammonium sulfate particles. The inverted probability distribution of the HGFs for particles has the advantage of high time resolution and high accuracy (Liu et al., 2011), and will be used in this study as the criterion to check the particle hygroscopicity evaluated from chemical characterization.

An automatic weather station was operated at the HaChi campaign field site. During the whole campaign, meteorological parameters including temperature, relative humidity, wind speed and direction were recorded continuously as 1 min data. In order to be comparable to the chemical data, the meteorological data were processed to $6 \mathrm{~h}$ average values.

\section{Methodology}

\section{$3.1 \quad \kappa$-Köhler theory}

Petters and Kreidenweis (2007) have proposed a single parameter method to describe the hygroscopic properties of aerosols, in which all of the chemical composition-dependent variables are merged into a single parameter $-\kappa$. The original Köhler equation is transformed into the $\kappa$-Köhler equation as

$$
S=\frac{\mathrm{HGF}^{3}-1}{\mathrm{HGF}^{3}-(1-\kappa)} \exp \left(\frac{4 \sigma_{\mathrm{s} / \mathrm{a}} M_{\mathrm{w}}}{\mathrm{RT} \rho_{\mathrm{w}} D_{0} \mathrm{HGF}}\right)
$$


Where $S$ represents the saturation ratio, which is another descriptive parameter of relative humidity, HGF represents the hygroscopic growth factor of particles, $\sigma_{\mathrm{s} / \mathrm{a}}$ is the surface tension of the solution-air interface, $M_{\mathrm{w}}$ is the molar weight of water, $R$ is the universal gas constant, $T$ is the absolute temperature, $\rho_{\mathrm{w}}$ is the density of water, $D_{0}$ is the diameter of the dry particle, and $\kappa$ is the hygroscopicity parameter. Values of $\kappa$ are between 0.5 and 1.4 for highly hygroscopic salts such as sodium chloride, between 0.01 and 0.5 for slightly to very hygroscopic organic species, and 0 for nonhygroscopic compounds (Petters and Kreidenweis, 2007).

The $\kappa$-Köhler theory is not only applicable to singlecomponent particles. For a multicomponent particle, where the Zdanovskii, Stokes and Robinson (ZSR) (Stokes and Robinson, 1966; Zdanovskii, 1948) mixing rule can be applied, the hygroscopicity parameter $\kappa$ is computed by weighting hygroscopicity parameters $\kappa_{i}$ of each component according to their volume fractions $\varepsilon_{i}$ as

$\kappa=\sum_{i} \varepsilon_{i} \kappa_{i}$

Ambient particles mainly consist of inorganic compounds, organic matter $(\mathrm{OM}), \mathrm{EC}$, insoluble crust debris and condensed water. The $\kappa$ values of individual components such as inorganic salts can be quantified from laboratory studies. Petters and Kreidenweis (2007) also suggested that $\kappa$ values can be derived from thermodynamic aerosol models (Clegg et al., 1998) and summarized $\kappa$ values for the most common inorganic compounds. For insoluble organic matter, elemental carbon and crust debris, the $\kappa$ values are 0 due to their hydrophobic properties. The exact $\kappa$ value of WSOC is hard or even impossible to get as it requires the complete knowledge of individual water-soluble organic compounds. The compounds making up WSOC vary with the measurement environment as well as the fractions of individual water-soluble organic compounds. Thus, the $\kappa$ value of WSOC varies spatially and temporally. Research on hygroscopic properties of organic compounds has become popular over the recent years (Wex et al., 2009; Petters et al., 2009). In this study, the hygroscopicity parameter $\kappa$ of WSOC is estimated at 0.3 , according to the results from Asa-Awuku et al. $(2010,2011)$ and Padro et al. (2010).

\subsection{Ion combination scheme}

The $\kappa$ value of a particle is calculated by weighting the $\kappa_{i}$ values of each individual particle component according to their volume fractions based on the ZSR mixing rule (Eq. 2). However, the chemical analysis provides only the concentrations of ions that have to be combined to the target compounds. Thus, a scheme developed from former studies (Gysel et al., 2007; Eichler et al., 2008) to combine cations and anions to inorganic compounds is introduced.

The most abundant inorganic ions $\mathrm{SO}_{4}{ }^{2-}, \mathrm{NO}_{3}{ }^{-}$and $\mathrm{NH}_{4}{ }^{+}$add up to more than half the total mass concentration
Table 2. The hygroscopicity parameter $\kappa$ of relevant particle components.

\begin{tabular}{|c|c|}
\hline Species & $\kappa^{\mathrm{a}}$ \\
\hline $\mathrm{NH}_{4} \mathrm{NO}_{3}$ & 0.68 \\
\hline $\mathrm{H}_{2} \mathrm{SO}_{4}$ & 0.68 \\
\hline $\mathrm{NH}_{4} \mathrm{HSO}_{4}$ & 0.56 \\
\hline$\left(\mathrm{NH}_{4}\right)_{2} \mathrm{SO}_{4}$ & 0.52 \\
\hline $\mathrm{NH}_{4} \mathrm{Cl}$ & 0.93 \\
\hline $\mathrm{NaCl}$ & 1.24 \\
\hline $\mathrm{Na}_{2} \mathrm{SO}_{4}$ & 0.76 \\
\hline $\mathrm{NaNO}_{3}$ & 0.87 \\
\hline $\mathrm{CaCl}_{2}$ & 0.78 \\
\hline $\mathrm{Ca}\left(\mathrm{NO}_{3}\right)_{2}$ & 1.10 \\
\hline $\mathrm{CaSO}_{4}$ & 0.00 \\
\hline $\mathrm{KCl}$ & 0.89 \\
\hline $\mathrm{K}_{2} \mathrm{SO}_{4}$ & 0.55 \\
\hline $\mathrm{KNO}_{3}$ & 0.53 \\
\hline $\mathrm{MgCl}_{2}$ & 0.98 \\
\hline $\mathrm{MgSO}_{4}$ & 0.24 \\
\hline $\mathrm{Mg}\left(\mathrm{NO}_{3}\right)_{2}$ & 0.63 \\
\hline WSOC & $0.3^{\mathrm{b}}$ \\
\hline \multicolumn{2}{|c|}{$\begin{array}{l}{ }^{\mathrm{a}}{ }_{\kappa} \text { of inorganic compounds } \\
\text { are derived from } \\
\text { ISORROPIA II (Fountoukis } \\
\text { and Nenes, 2007). } \\
\mathrm{b} \kappa \text { of WSOC is estimated } \\
\text { based on the studies of } \\
\text { Asa-Awuku et al. (2010, } \\
\text { 2011) and Padro et al. (2010) }\end{array}$} \\
\hline
\end{tabular}

of all chemically analyzed ions. Consequently, $\mathrm{H}_{2} \mathrm{SO}_{4}$ and the inorganic salts $\mathrm{NH}_{4} \mathrm{NO}_{3},\left(\mathrm{NH}_{4}\right)_{2} \mathrm{SO}_{4}$ and $\mathrm{NH}_{4} \mathrm{HSO}_{4}$, which are composed of these three ions, are included in this combination scheme. $\mathrm{Ca}^{2+}$ is relatively abundant in coarse particles, so calcium salts $\mathrm{CaSO}_{4}, \mathrm{CaCl}_{2}$ and $\mathrm{Ca}\left(\mathrm{NO}_{3}\right)_{2}$ are included in the combination scheme. Moreover, sodium salts, potassium salts and magnesium salts are concerned, although they are in trace amounts. Thus, up to 17 inorganic salts are involved in this scheme. ISORROPIA II (Fountoukis and Nenes, 2007) is a thermodynamic equilibrium aerosol model that is favorable for this study because all analyzed inorganic ionic species are considered in this model to predict the equilibrium water content of a multicomponent aerosol system. A comprehensive evaluation using laboratory experiments and other aerosol models confirms the sensitivity and stability of the ISORROPIA II model in high RH conditions (Fountoukis and Nenes, 2007). The HGFs that are determined from the absorbed water derived by the ISORROPIA II model are transformed to the modeled $\kappa$ values using Eq. (1). The modeled $\kappa$ values of all inorganic compounds involved in this study are listed in Table 2. 

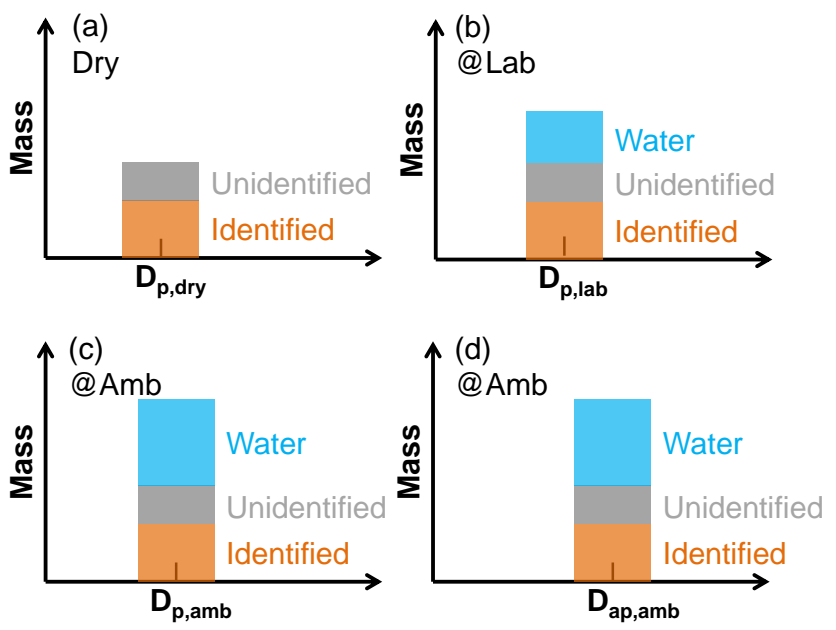

Fig. 1. Sketches of particle composition under different conditions: (a) is for dry particles; (b) is for particles under laboratory conditions; (c) and (d) are for particles under ambient conditions. In the former three panels $(\mathbf{a}, \mathbf{b}, \mathbf{c})$, particles are indicated with mobility diameters, while in the last panel (d) particles are indicated with aerodynamic diameters. The diameters of particles vary under different conditions due to the variation of equilibrium water. The "identified" represents the summation of all chemically analyzed species such as inorganics, OM and EC. The amounts of identified and unidentified matter remain constant under all conditions.

\subsection{Derivation algorithm of $\kappa$ from chemical composition}

Dry particles, with their volume equivalent diameters of $D_{\text {p,dry }}$, are assumed to consist of inorganic compounds, OM, EC and unidentified matter in this study (Fig. 1a). Before weighing, the impactor samples were equilibrated at $52 \%$ and $20^{\circ} \mathrm{C}$ for at least $48 \mathrm{~h}$. Under this condition, the particles will generally contain water and their diameters will equilibrate at $D_{\mathrm{p} \text {,lab }}$ rather than $D_{\mathrm{p} \text {,dry }}$ as illustrated in Fig. $1 \mathrm{~b}$ because some of the particulate mass is generally hygroscopic and the laboratory condition is not dry enough for particles to effloresce if they were sampled at a higher ambient RH. Particles sampled in the ambient also contain liquid water. However, the ambient RHs are not necessarily the same as the controlled RHs under the laboratory condition for substrate equilibration, so the equilibrium water content of particles in the ambient differ from in the lab, as do their wet diameters $\left(D_{\mathrm{p}, \mathrm{amb}}\right)$ (Fig. 1c). During sampling with a BLPI, it is the aerodynamic diameters of the particles $\left(D_{\mathrm{ap}, a m b}\right)$ that determine on which impactor stage the sampled particles are deposited (Fig. 1d). The aerodynamic diameter of a particle is transformed from the volume equivalent diameter by the square root of the particle density in units of grams per cubic centimeter.

The total particulate mass concentration is determined from substrate weighing. The mass concentrations of EC, OC and WSOC are determined from chemical analysis, and the

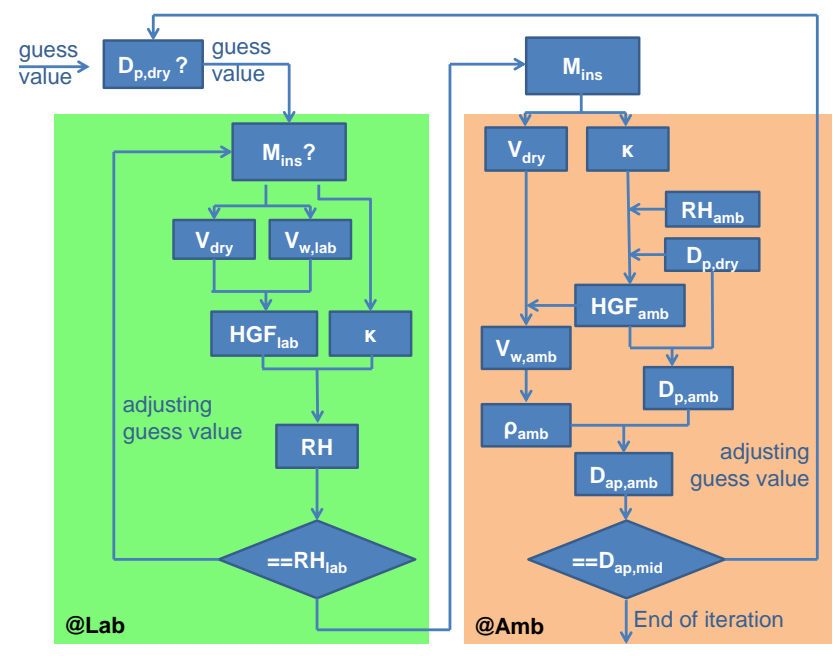

Fig. 2. Schematic representation of the iterative algorithm for evaluating $\kappa$ values of particles: the laboratory-related variables and calculations are displayed on the green background, and the ambientrelated variables and calculations are displayed on the brown background.

mass concentration of OM is converted from OC. Turpin and Lim (2001) summarized published literature and proposed an $\mathrm{OM} / \mathrm{OC}$ conversion factor of 1.6 for urban aerosols. Xing et al. (2013) calculated the OM/OC mass ratios with two different methods and reported the factor of 1.59 and 1.68 during summertime in Tianjin. So a factor of 1.6 is used to convert the mass concentration of $\mathrm{OC}$ to that of $\mathrm{OM}$ in this work. The mass concentrations of inorganic compounds are derived from the ion combination scheme described in Sect. 3.2. The gap between the total particulate mass concentration and the summation of all chemically analyzed components is considered to be the unidentified matter and absorbed water. To calculate $\kappa$ values based on the ZSR mixing rule, an algorithm to predict the amount of the unidentified matter is needed.

Prior to applying the algorithm, an assumption has been made that all particles collected on one sampled substrate are identical in both the aerodynamic diameters and the particle chemical composition due to the lack of more detailed information. The aerodynamic diameters of particles are postulated to be equal to the geometric mean diameter ( $\left.D_{\mathrm{ap}, \mathrm{mid}}\right)$ of the corresponding impactor stage. Another simplification is made to facilitate the algorithm merging the insoluble part of OM, EC and the unidentified matter into insoluble matter. Now the particles with aerodynamic diameters of $D_{\mathrm{ap} \text {,mid }}$ comprise three parts: the soluble matter such as inorganics and WSOC, the insoluble matter and absorbed water.

The iterative algorithm contains two sections. The first section calculates values under controlled laboratory conditions, while the second section calculates values under ambient conditions (Fig. 2). Initial guesses for the particle values of dry diameter $\left(D_{\text {dry }}\right)$ and the mass concentration of insoluble matter $\left(M_{\text {ins }}\right)$ are given. The amount of water taken up by 
hygroscopic growth in the controlled laboratory conditions is determined by subtracting the sum of all chemically analyzed components and $M_{\text {ins }}$ from the weighed mass concentration. Then the volume concentration of the dry particulate mass $\left(V_{\mathrm{dry}}\right)$ and that of absorbed water $\left(V_{\mathrm{w}, \mathrm{lab}}\right)$ are available, and HGF of particles under the controlled laboratory conditions $\left(\mathrm{HGF}_{\mathrm{lab}}\right)$ is derived from the cubic root of the wet particle volume $\left(V_{\mathrm{dry}}+V_{\mathrm{w}, \mathrm{lab}}\right)$ over the cubic root of the dry particle volume $\left(V_{\text {dry }}\right)$. Also, $\kappa$ is derived through the ZSR mixing rule as all components of the dry particle and their fractions are now available. By substituting $\mathrm{HGF}_{\text {lab }}$ and $\kappa$ into Eq. (1), $\mathrm{RH}$ is calculated. This calculated $\mathrm{RH}$ is compared with $\mathrm{RH}$ of the laboratory condition for equilibration $\left(\mathrm{RH}_{\mathrm{lab}}=52 \%\right)$. If these two values differ, the algorithm returns to the beginning of the first section and tries to adjust the initial guess of $M_{\text {ins. }}$.

If $\mathrm{RH}_{\text {lab }}$ matches the calculated $\mathrm{RH}$ of the first section, the iterative algorithm comes to the second section. With the determined $M_{\text {ins }}, V_{\text {dry }}$ and $\kappa$ values are derived as in the first section. During BLPI sampling, the ambient relative humidity $\left(\mathrm{RH}_{\mathrm{amb}}\right)$ was measured parallel with an AWS. Substituting $\mathrm{RH}_{\mathrm{amb}}, D_{\mathrm{p} \text {,dry }}$ as well as $\kappa$ into Eq. (1) and solving the equation, the $\mathrm{HGF}$ in the ambient condition $\left(\mathrm{HGF}_{\mathrm{amb}}\right)$ is derived. $D_{\mathrm{p}, \mathrm{amb}}$ is calculated by $D_{\mathrm{p} \text {,dry }}$ times $\mathrm{HGF}_{\mathrm{amb}}$, and the wet particle volume is calculated by $V_{\text {dry }}$ times $\mathrm{HGF}_{\mathrm{amb}}$ cubed. The amount of absorbed water in the ambient condition $\left(V_{\mathrm{w}, \mathrm{amb}}\right)$ is obtained by subtracting $V_{\text {dry }}$ from the wet particle volume. The density of the wet particle $\left(\rho_{\mathrm{amb}}\right)$ is derived as the mass concentrations of all components in the wet particle are determined. Then the aerodynamic diameter of the wet particle $\left(D_{\mathrm{ap}, \mathrm{amb}}\right)$ is transformed from the volume equivalent diameter $\left(D_{\mathrm{p}, \mathrm{amb}}\right)$ by a factor of the square root of $\rho_{\mathrm{amb}}$. If $D_{\mathrm{ap}, \mathrm{amb}}$ is equal to $D_{\mathrm{ap} \text {,mid }}$, which is the geometric mean diameter of the corresponding impactor stage, the iterative process ends and the $\kappa$ value of the dry particle is evaluated. Otherwise the algorithm goes back to the very beginning, to adjust the initial guess of $D_{\text {dry }}$ and to re-execute the whole process.

\section{Results and discussion}

\subsection{Meteorology overview}

Figure 3 provides a comprehensive view of meteorological conditions during the campaign as well as the start and end times of sampling using a BLPI. The temperature and RH series show distinct diurnal cycles. The average temperatures corresponding to sampling during daytime and to sampling during nighttime are $29.0 \pm 3.5^{\circ}$ and $24.3 \pm 2.4^{\circ}$, respectively. And the daytime and nighttime average RHs are $65.5 \% \pm 14.6 \%$ and $82.4 \% \pm 11.6 \%$, respectively. The wind speed also shows a clear diurnal variation. Wind gradually strengthens in the daytime and diminishes when night comes. Wind direction does not show a diurnal cycle, but

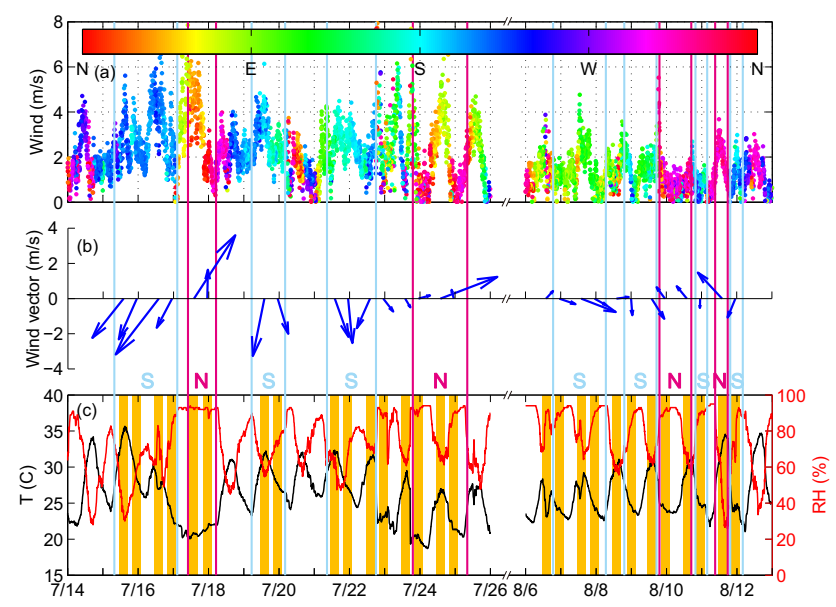

Fig. 3. Series of meteorological parameters during the campaign. (a) shows wind time series with different colors of dots indicating wind directions. (b) shows $6 \mathrm{~h}$ average wind vector during each aerosol sampling period. (c) shows temperature and RH time series. The orange bars indicate the sampling periods using BLPI. Samples are classified into two patterns: the northerly pattern $(\mathrm{N})$ and the southerly pattern (S) and a few samples are not classified into any patterns.

shows a cycle of several days. Wind direction is determined by synoptic patterns. During summer, the western Pacific subtropical high strengthens and pushes northward. The NCP is located at the west of the subtropical high and is controlled by the southerly wind. The NCP is also under the influence of the westerlies. As the waves in the westerlies moves eastward, the site shifts from in front of the trough to behind of the trough. Accordingly, the wind shifts from southerly to northerly.

When the site is under the influence of different synoptic patterns, wind direction shifts radically and aerosol source regions change. Thus, aerosol samples are classified into several patterns according to wind directions during sampling. If wind direction is stable during the $6 \mathrm{~h}$ sampling, and the average wind is southerly, the corresponding sample is tagged with the southerly pattern, or " $S$ " pattern, as indicated in Fig. 3. If wind direction is stable during the $6 \mathrm{~h}$ sampling and the average wind is northerly, the sample is tagged with the northerly pattern, or "N" pattern. For some aerosol samples such as the one in the daytime, 6 August, wind direction is disordered and there is no preferred wind direction during the sampling. These samples are not classified into any patterns. The differences of aerosol characteristics between the southerly pattern and the northerly pattern will be discussed in the following sections.

\subsection{Particle's chemical composition}

The average particulate particle's chemical composition during the HaChi summer campaign is displayed in Table 3. 
Table 3. The average particle chemical composition during the HaChi summer campaign. All mass concentrations are in the unit of micrograms per cubic meter.

\begin{tabular}{cccccccccccc}
\hline$D_{\mathrm{p}}(\mu \mathrm{m})$ & total mass & $\mathrm{Na}^{+}$ & $\mathrm{NH}_{4}{ }^{+}$ & $\mathrm{K}^{+}$ & $\mathrm{Mg}^{2+}$ & $\mathrm{Ca}^{2+}$ & $\mathrm{Cl}^{-}$ & $\mathrm{NO}_{3}{ }^{-}$ & $\mathrm{SO}_{4}{ }^{2-}$ & $\mathrm{EC}$ & $\mathrm{OM}$ \\
\hline 0.030 & 1.15 & 0.00 & 0.02 & 0.00 & 0.00 & 0.04 & 0.03 & 0.05 & 0.07 & 0.17 & 0.89 \\
0.061 & 2.08 & 0.00 & 0.08 & 0.00 & 0.00 & 0.04 & 0.02 & 0.08 & 0.27 & 0.25 & 0.93 \\
0.122 & 5.47 & 0.01 & 0.42 & 0.01 & 0.00 & 0.10 & 0.04 & 0.40 & 0.96 & 0.49 & 1.59 \\
0.235 & 14.17 & 0.01 & 1.16 & 0.04 & 0.00 & 0.05 & 0.18 & 2.01 & 3.27 & 0.83 & 1.99 \\
0.458 & 38.50 & 0.05 & 3.24 & 0.22 & 0.01 & 0.10 & 0.64 & 4.81 & 8.04 & 1.26 & 2.88 \\
0.917 & 26.90 & 0.03 & 1.93 & 0.10 & 0.02 & 0.29 & 0.53 & 3.76 & 5.52 & 1.26 & 3.57 \\
1.98 & 12.82 & 0.03 & 0.33 & 0.04 & 0.03 & 0.20 & 0.28 & 1.74 & 1.36 & 0.36 & 1.18 \\
4.01 & 11.08 & 0.03 & 0.14 & 0.01 & 0.05 & 0.44 & 0.29 & 1.78 & 0.93 & 0.12 & 0.68 \\
\hline
\end{tabular}

The particulate mass size distribution shows a unimodal pattern. The peak of the particulate mass size distribution appears around $450 \mathrm{~nm}$ (Fig. 4a). The position of the peak is in good agreement with a former study in the NCP using a fivestage BLPI reporting the peak of the particulate mass size distribution between 0.42 and $1.2 \mu \mathrm{m}$ (van Pinxteren et al., 2009). The sum of the particulate mass concentrations is up to $112.2 \mu \mathrm{g} \mathrm{m}^{-3}$. As the maximum cutoff diameter sampled with a BLPI during the HaChi summer campaign is $8 \mu \mathrm{m}$, the total mass concentration is close to $\mathrm{PM}_{10}$ mass concentration. The average $\mathrm{PM}_{10}$ mass concentrations observed in a former study (van Pinxteren et al., 2009) at the urban and suburban sites in the Beijing area were 133 and $112 \mu \mathrm{g} \mathrm{m}^{-3}$, respectively. For the main inorganic ionic species $\mathrm{SO}_{4}{ }^{2-}$, $\mathrm{NO}_{3}{ }^{-}$and $\mathrm{NH}_{4}{ }^{+}$, the average mass concentrations during the HaChi campaign were 20.4, 14.6 and $7.3 \mu \mathrm{g} \mathrm{m}^{-3}$, respectively, while the corresponding values observed at the two sites in Beijing were $20-25,10-16,8-10 \mu \mathrm{g} \mathrm{m}^{-3}$, respectively (van Pinxteren et al., 2009). The average mass concentration of WSOC in this study is $5.4 \mu \mathrm{g} \mathrm{m}^{-3}$, which is in good agreement with the former measurement of van Pinxteren et al. (2009) where WSOC mass concentrations are $3.8 \mu \mathrm{g} \mathrm{m}^{-3}$ for the urban site and $5.7 \mu \mathrm{g} \mathrm{m}^{-3}$ for the suburban site. The results of the total mass concentration and those of the main chemical species are consistent with the former results measured during summer 2006 in Beijing, indicating the relatively constant aerosol emission strength in the NCP in recent years. Meanwhile, the good agreement of the two sets indicates the good quality and high reliability of chemical data in this study. Further analysis shows that the particulate mass concentration is largely determined by the synoptic patterns. In the southerly pattern, the mass concentration is as high as $149.7 \mu \mathrm{g} \mathrm{m}^{-3}$, but in the northerly pattern, this value is only $70.8 \mu \mathrm{g} \mathrm{m}^{-3}$. The concentrations of species show similar differences between two synoptic patterns.

As one of the main components of atmospheric aerosol particles sampled during the HaChi summer campaign, OM is of particular importance for the ultrafine particles. For particles of around $30 \mathrm{~nm}, 77.3 \%$ of the particulate mass concentration is composed of OM (Fig. 4b). However, with the

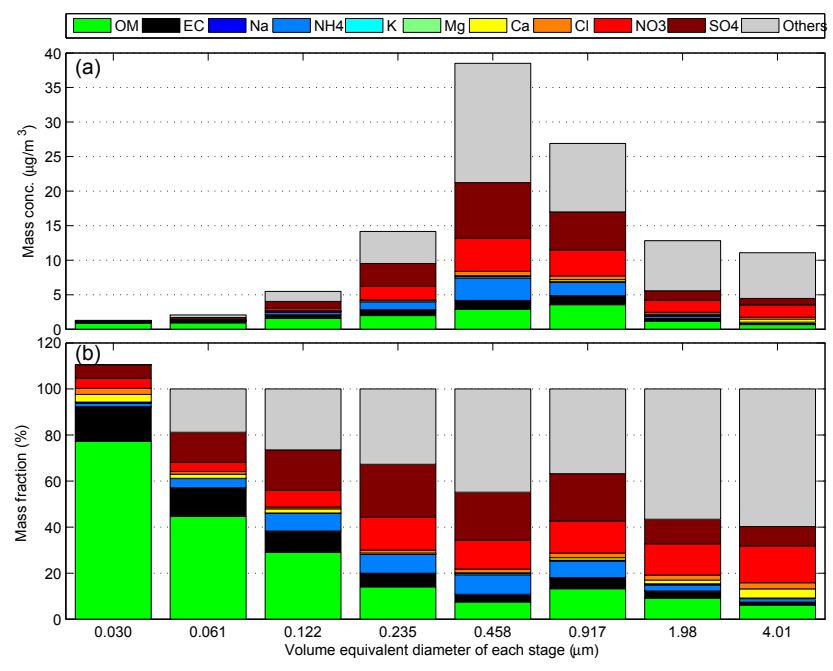

Fig. 4. The average size distributions of the particulate mass and the chemical composition during the HaChi campaign. Panel (a) shows the mass concentration of all species and panel (b) shows the relative mass fractions in individual impactor stage. OM is converted from OC by a conversion factor of 1.6 (Turpin and Lim, 2001; Xing et al., 2013).

increasing particle size, the fraction of $\mathrm{OM}$ in the particulate mass concentration decreases. For particles larger than $150 \mathrm{~nm}$, the mass fractions of OM are less than $20 \%$.

The inorganic compounds are the major components for particles in the range of $150 \mathrm{~nm}-1 \mu \mathrm{m}$. The average mass fractions of inorganic ions are 47.4, 44.4 and $45.2 \%$ for particles of around 250, 450 and $900 \mathrm{~nm}$, respectively; however, for ultrafine particles, the inorganic compounds are less abundant. For example, for particles of around $30 \mathrm{~nm}$, the inorganic ions account for only $18.6 \%$ of the particulate mass, which is less than half of the mass fraction of the inorganic ions for particles between $150 \mathrm{~nm}$ and $1 \mu \mathrm{m}$. Thus, the differences between the inorganic ion fractions for particles of different sizes are significant. $\mathrm{SO}_{4}{ }^{2-}$ is the most abundant inorganic ion, followed by $\mathrm{NO}_{3}{ }^{-}$and $\mathrm{NH}_{4}{ }^{+}$. These three inorganic ions make up more than $90 \%$ of the total ion mass concentration. The rest of the inorganic ionic species $\mathrm{CCa}^{2+}$, 


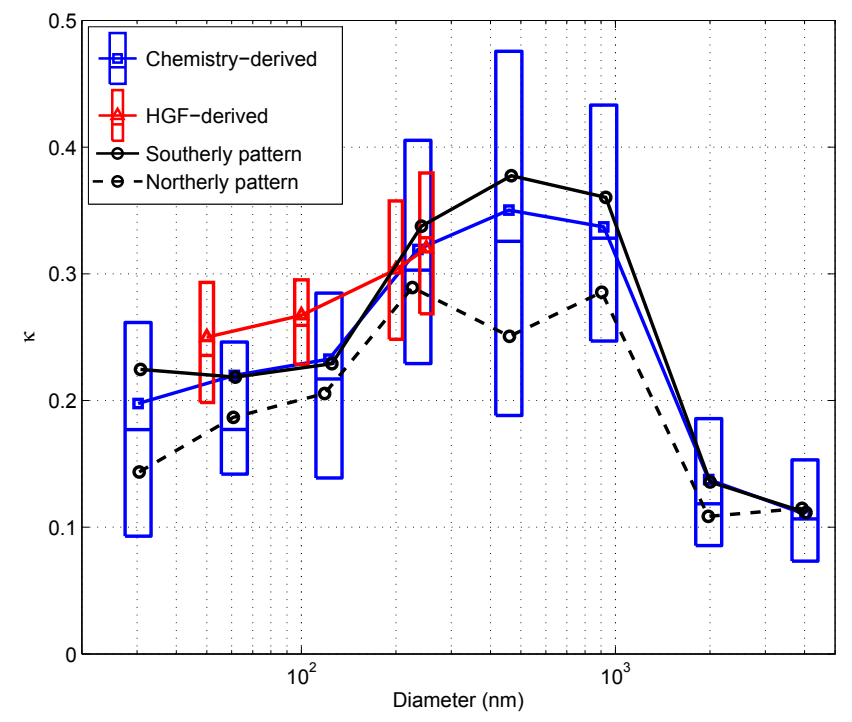

Fig. 5. The average $\kappa$ curves during the campaign. Blue curve and boxes show the chemistry-derived $\kappa$ values. Red curve and boxes show the HGF-derived $\kappa$ values. Blue squares and red triangles represent the campaign-average $\kappa$ values. The central line, bottom and upper edges of boxes represent the medians, 25th percentile and 75th percentile of $\kappa$ values for the individual impactor stage or the individual particle diameter. The solid curve and dashed curve represent average values in the southerly pattern and in the northerly pattern, respectively.

$\left.\mathrm{Na}^{+}, \mathrm{K}^{+}, \mathrm{Mg}^{2+}, \mathrm{Cl}^{-}\right)$are relatively sparse in the particles sampled during the HaChi summer campaign.

The sum of the mass concentrations of all chemically analyzed species doesn't match the weighed particulate mass concentration. Apart from the absorbed water, there is a part of particulate matter remaining unidentified; and the larger particles are, the larger fraction of unidentified particle matter. Particles of around $30 \mathrm{~nm}$ are exceptions, as the summed mass concentration of the analyzed particle components exceed the weighed mass concentration. This is probably caused by the analytical uncertainties of the chemical analysis, which are relatively high compared to the relatively low mass concentrations. The unidentified matter is associated with the insoluble material such as soil debris and mineral dust, as well as the condensed water. When evaluating the particle hygroscopicity, the amount of condensed water has to be subtracted from the particulate mass concentration.

\subsection{Characteristics of $\kappa$ derived from the particle's chemical composition}

Based on the iterative algorithm, $\kappa$ values as well as dry diameters are derived from the corresponding chemical composition. The average $\kappa$ value variation is shown in Fig. 5.

The distribution of $\kappa$ values appears in three modes: the highly hygroscopic mode, the less hygroscopic mode and the nearly hydrophobic mode. The highly hygroscopic mode

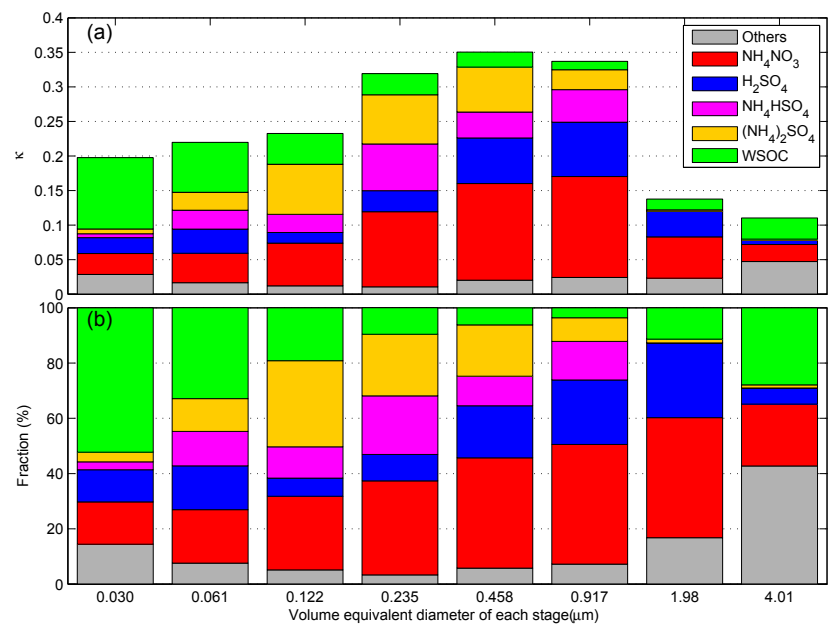

Fig. 6. Average contributions of main species to $\kappa$ values. The upper panel shows the absolute contributions of each species, and the bottom panel shows the relative contributions. WSOC and several inorganic compounds are explicitly displayed due to their significant roles in aerosol's hygroscopic properties. Other inorganic salts are merged into a group named "Others" due to their relatively minor contributions.

ranges from $150 \mathrm{~nm}$ to $1 \mu \mathrm{m}$. The average $\kappa$ value in this mode is greater than 0.3 with the peak value of 0.35 around $450 \mathrm{~nm}$. Particles in the less hygroscopic mode are smaller than $150 \mathrm{~nm}$ with the average $\kappa$ value slightly greater than 0.2 . Particles in the nearly hydrophobic mode are larger than $1 \mu \mathrm{m}$ and the average $\kappa$ value slightly greater than 0.1 . The variance of $\kappa$ values with size indicates the variance of the particle's chemical compositions, which results from diverse sources of particles with different sizes.

The highly hygroscopic particles are mainly found in the accumulation mode. These particles grow from smaller particles by coagulation, condensation and experience various atmospheric aging processes. Their relatively large surface area concentration and the absorbed water facilitate heterogeneous chemical reactions. Due to the high concentrations of gaseous pollutants such as $\mathrm{NO}_{\mathrm{x}}, \mathrm{SO}_{2}$ and $\mathrm{NH}_{3}$ (Xu et al., 2011), nitrates, sulfates and ammonium salts are abundant in particles in the accumulation mode as discussed in Sect. 4.2. The chemical analysis shows that more than half of the particulate mass concentration in the highly hygroscopic mode is composed of inorganic matter, mostly those of $\mathrm{SO}_{4}{ }^{2-}, \mathrm{NO}_{3}{ }^{-}$and $\mathrm{NH}_{4}{ }^{+}$. The large mass fraction of inorganic matter in the particles results in particles that are highly hygroscopic, and $\mathrm{NH}_{4} \mathrm{NO}_{3}, \mathrm{H}_{2} \mathrm{SO}_{4}, \mathrm{NH}_{4} \mathrm{HSO}_{4}$ and $\left(\mathrm{NH}_{4}\right)_{2} \mathrm{SO}_{4}$ together explain 87.1, 88.1 and $89.2 \%$ of the hygroscopicity for particles of around 250,450 and $900 \mathrm{~nm}$, respectively (Fig. 6).

Particles in the less hygroscopic mode originated mainly from nucleation and condensation of low-volatile organic compounds and from primary emission of biomass combustion (Wiedensohler et al., 2009). OM is the predominant 
component for particles in this mode and contributes as much as two-thirds of the total mass for particles of around $30 \mathrm{~nm}$. A large part of $\mathrm{OM}$ is insoluble and the water-soluble part of OM performs weakly hygroscopic. Mader et al. (2004) reported that the WSOC fraction contributes $10-50 \%$ of the carbon mass in eastern Asia. WSOC makes a significant contribution to the hygroscopic properties of the ultrafine particles. More than half $(52.2 \%)$ of the $\kappa$ values for particles of around $30 \mathrm{~nm}$ is contributed by WSOC (Fig. 6). For those particles, the contribution of WSOC to hygroscopicity is even larger than that of inorganics. Thus, hygroscopicity of particles smaller than $150 \mathrm{~nm}$ would be underestimated if only inorganics are taken into account while neglecting WSOC's contribution. With increasing particle size, the contribution of WSOC to hygroscopicity decreases; this is consistent with former studies (Achtert et al., 2009) demonstrating the poor correlation between WSOC and growth factors for particles of $250 \mathrm{~nm}$. About $60 \%$ of the mass for particles larger than $1 \mu \mathrm{m}$ is chemically unidentified, and is assumed to be mineral dust as well as absorbed water. Due to the large fraction of mineral dust, particles in this mode are nearly hydrophobic.

The influence of synoptic patterns on aerosol hygroscopicity is evident. It can be seen in Fig. 5 that aerosols in the southerly pattern are more hygroscopic than aerosols in the northerly pattern (solid line vs. dashed line). The largest difference appears in the highly hygroscopic mode $\left(150 \mathrm{~nm}<D_{\mathrm{p}}<1 \mu \mathrm{m}\right)$. The average $\kappa$ value of particles in this mode in the southerly pattern is up to 0.38 , while the $\kappa$ value of particles within the same size range in the northerly pattern is less than 0.3 . For particles in the less hygroscopic mode $\left(D_{\mathrm{p}}<150 \mathrm{~nm}\right)$ and in the nearly hydrophobic mode $\left(D_{\mathrm{p}}>1 \mu \mathrm{m}\right)$, the differences of $\kappa$ between two synoptic patterns are smaller. The differences of $\kappa$ in two synoptic patterns can be explained by the differences of air mass origin. The campaign site is located at the northernmost of the NCP and to the south of it are highly industrialized areas with a dense population and where large amounts of aerosols and gaseous pollutants such as $\mathrm{SO}_{2}$ and $\mathrm{NO}_{\mathrm{x}}$ are emitted (Xu et al., 2011). During the southerly pattern, southerly wind dominates and aerosols and pollutant gases emitted from the central NCP are transported to the campaign site and accumulate in this region as the mountains in the north obstruct the transport pass. The high RH conditions in the summer facilitate the conversion of gaseous pollutants to particulate matter through heterogeneous reactions, making particles more hygroscopic. While during the northerly pattern, the wind blows southward and air masses pass over relatively remote desert plateau areas before reaching the campaign site. So the particles contain more mineral dust. Also, the concentration of gaseous pollutants is lower than in the southerly pattern (Xu et al., 2011) due to the scarcity of emission sources, and the gas-to-particle conversion is weak. Therefore, the hygroscopicity of particles in the northerly pattern is lower than the hygroscopicity of particles in the southerly pattern.

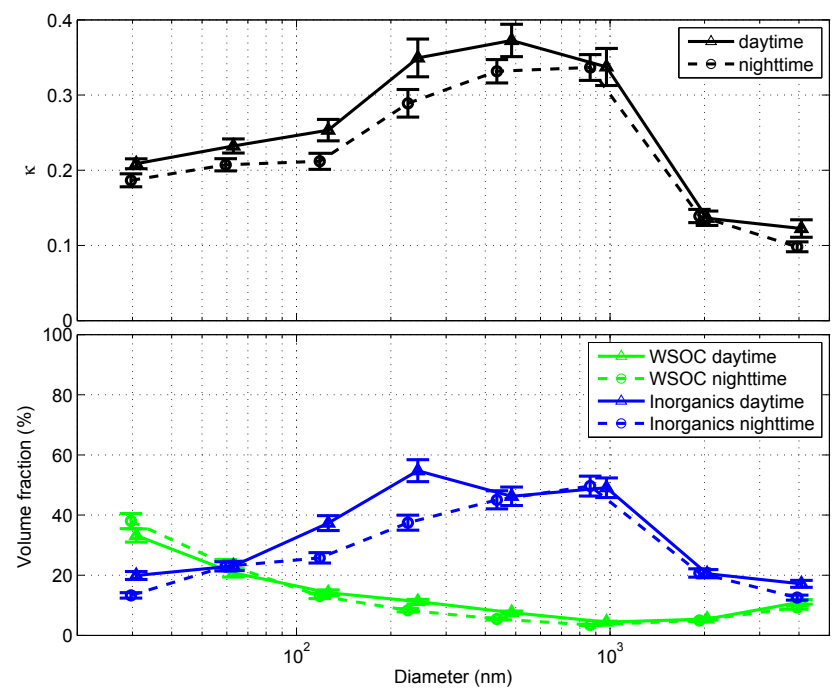

Fig. 7. The upper panel (a) shows the average $\kappa$ curves with uncertainties derived from the daytime and the nighttime measurements, respectively. The bottom panel (b) shows the corresponding volume fractions of WSOC and overall inorganics with uncertainties.

An HH-TDMA system was used for the HGF measurement during the HaChi summer campaign. Probability distribution functions of HGF for particles with dry diameters of 50,100, 200, and $250 \mathrm{~nm}$ were obtained under high RH conditions from HH-TDMA measurements (Liu et al., 2011). HGF-derived $\kappa$ values are calculated from HGF using Eq. (1). An HH-TDMA system has the advantage of high accuracy and was carefully maintained and calibrated every day during the campaign (Liu et al., 2011), so HGFderived $\kappa$ values are used as the criterion to test the quality of chemistry-derived $\kappa$ values. HGF-derived $\kappa$ values overlap with chemistry-derived $\kappa$ values in the diameter range of 50-250 nm (Fig. 5) and two sets of $\kappa$ values agree well. For particles of 200 and $250 \mathrm{~nm}$, HGF-derived $\kappa$ values and chemistry-derived $\kappa$ values are almost equal with differences of 1.9 and $0.7 \%$, respectively. For smaller particles such as particles of $100 \mathrm{~nm}$, chemistry-derived $\kappa$ values are $13.8 \%$ smaller than HGF-derived $\kappa$ values. This difference is thought to be caused by the relatively larger uncertainty of chemistry-derived $\kappa$ values for smaller particles. The uncertainty of chemistry-derived $\kappa$ values arise for several reasons: volatile species such as $\mathrm{NH}_{4} \mathrm{NO}_{3}$ might evaporate during sampling with BLPI, which is a low pressure device (Chang et al., 2000); particulate mass weighing and laboratory analysis of particle chemical composition would introduce errors; also the unbalance of charge between cations and anions would cause errors in the ion combination process (Eichler et al., 2008). Together, these account for the uncertainty of chemistry-derived $\kappa$ values. 


\subsection{Difference of hygroscopicity between daytime and nighttime}

During the campaign measurement, aerosol sampling was conducted twice a day - one measurement during the daytime and the other during the nighttime. Daytime and nighttime $\kappa$ values with uncertainties are derived from the corresponding chemical data and the average $\kappa$ curves as a function of diameter are displayed in Fig. 7a. Daytime and nighttime curves show similar trends. Particles smaller than $700 \mathrm{~nm}$ are about $10 \%$ more hygroscopic during daytime than during nighttime, and the differences are statistically significant. For particles larger than $700 \mathrm{~nm}$, no significant difference in hygroscopicity was observed. The enhanced hygroscopicity during daytime for particles between 50 and $250 \mathrm{~nm}$ corresponds to the results derived from HH-TDMA data (Liu et al., 2011).

The hygroscopic behavior of a particle can be determined by its chemical composition based on the ZSR mixing rule. The average volume fractions with uncertainties of inorganic compounds and WSOC for particles sampled with the BLPI are displayed in Fig. 7b. In general, differences in the volume fraction of inorganics $\left(\mathrm{VF}_{\text {inorg }}\right)$ are consistent with differences in $\kappa$ values. Particles of around $250 \mathrm{~nm}$ show the largest difference in $\kappa$ values as well as the largest difference in $\mathrm{VF}_{\text {inorg. }}$. However, there are few exceptions. No differences in $\mathrm{VF}_{\text {inorg }}$ are observed for particles of around $60 \mathrm{~nm}$ and around $450 \mathrm{~nm}$, although apparent differences in the $\kappa$ values of the corresponding size ranges exist. This can be explained by the differences among $\kappa$ values of inorganics. The differences in the volume fractions of WSOC are less than $5 \%$ and statistically insignificant for the daytime and nighttime measurements, which are much smaller than those for inorganics (Fig. 7b). Furthermore, WSOC is a less hygroscopic particle component compared with inorganics. So WSOC is believed to have little influence on the differences in $\kappa$ values between daytime and nighttime.

The diurnal evolution of the planetary boundary layer (PBL) can explain the differences in particle hygroscopicity between daytime and nighttime. At night, the PBL is shallow. Some aged particles are trapped aloft due to the sudden collapse of the PBL when night begins. In the morning, as the incoming solar radiation starts to heat the ground, the PBL gradually develops and increases in thickness. Particles trapped aloft at nighttime now are involved in the PBL again and are mixed downward by entrainment. Commonly, the particles aloft have experienced the aging process for at least one day and are more hygroscopic than newly emitted particles. Thus, particles are more hygroscopic after mixing. Moreover, the aging process is another way to enhance particle hygroscopicity. Photochemical reactions can accelerate the aging process of particles. With the help of the $\mathrm{OH}$ radical, which exists only in the presence of short radiation, $\mathrm{SO}_{2}$ is oxidized to a higher oxidation state and adsorbed by particles. $\mathrm{SO}_{2}$ can also be oxidized through heterogeneous re- actions. In the high RH conditions, particles absorb water and serve as a medium for reactions (Seinfeld and Pandis, 1998). Thus, the aged particles contain more soluble materials such as sulfate salts, and become more hygroscopic. Shift of nitrate partitioning between gas state and ion state when temperature and RH changes between daytime and nighttime also influence particle hygroscopicity (Morino et al., 2006). However, due to the lack of $\mathrm{HNO}_{3}$ measurements, the influence of nitrate partitioning cannot be quantified. After sunset, the PBL collapses and become shallow. The enhanced black carbon emission at night is observed during the campaign (Ma et al., 2011), and the high ratio of externally mixed black carbon at night proved the enhanced black carbon emission (Ma et al., 2012). The more hydrophobic black carbon a particle contains, the less hygroscopic it is. The shallow PBL further amplifies the impact of black carbon emission to particle hygroscopicity. The diurnal variation of particle hygroscopicity was also observed in other measurements (Rissler et al., 2006).

\subsection{Parameterization of $\kappa$ based on ion mass fractions}

Hygroscopic properties of particles can be evaluated using an H-TDMA or a CCN counter, and the chemical composition of particles serves as another way to evaluate the hygroscopicity of particles. The chemical-dependent method can be used to evaluate the hygroscopic behavior of particles in the range from tens of nanometers to several microns, while an $\mathrm{H}$-TDMA-dependent or CCN-dependent method is only suitable for particles of up to $300 \mathrm{~nm}$. Based on the iterative algorithm described in Sect. 3.3, the hygroscopicity parameter $\kappa$ can be estimated from the particulate mass concentration and the chemical components. The results are fairly good but the iterative algorithm is of high computational cost. Hence, a parameterization method to evaluate $\kappa$ values is necessary, which is computationally efficient at the expense of accuracy.

There already exists a parameterization scheme to predict the hygroscopicity parameter $\kappa$ from the particle's chemical composition (Gunthe et al., 2009; Dusek et al., 2010):

$\kappa=\kappa_{\text {org }} \cdot f_{\text {org }}+\kappa_{\text {inorg }} \cdot f_{\text {inorg }}$.

Where $\kappa_{\text {org }}$ and $\kappa_{\text {inorg }}$ are the hygroscopicity parameters for organic and inorganic components, and $f_{\text {org }}$ and $f_{\text {inorg }}$ are the mass concentration ratios of organics and inorganics to the sum of all chemically analyzed species, respectively. However, this scheme was developed based on the particle chemical composition measured with an aerosol mass spectrometer (AMS; Jayne et al., 2000). An AMS can analyze the mass concentration of inorganic ionic species such as $\mathrm{SO}_{4}{ }^{2-}$, $\mathrm{NO}_{3}{ }^{-}, \mathrm{NH}_{4}{ }^{+}$and $\mathrm{OM}$, but cannot analyze those of the inorganic refractory species such as sea salt nor water-insoluble species such as EC and mineral dust. So the sum of mass concentrations of all species analyzed with an AMS is less than the particulate mass concentration. Thus, $f_{\text {org }}$ and $f_{\text {inorg }}$ are significantly larger than the mass fractions of organics and 
Table 4. Correlation coefficients and slopes between $\kappa$ values and mass fractions of individual ions and WSOC.

\begin{tabular}{lrr}
\hline Species & Slope & $R^{2}$ \\
\hline $\mathrm{Na}$ & -5.669 & 0.0142 \\
$\mathrm{NH}_{4}$ & 2.409 & 0.4452 \\
$\mathrm{~K}$ & 5.839 & 0.0284 \\
$\mathrm{Mg}$ & -17.72 & 0.0532 \\
$\mathrm{Ca}$ & -0.0728 & 0.0003 \\
$\mathrm{Cl}$ & -1.422 & 0.0215 \\
$\mathrm{NO}_{3}$ & 0.8673 & 0.1335 \\
$\mathrm{SO}_{4}$ & 1.079 & 0.7291 \\
$\mathrm{WSOC}$ & 0.1227 & 0.0058 \\
\hline
\end{tabular}

inorganics, respectively. As the AMS-based parameterization scheme is not suitable for our study, we want to set up a new parameterization scheme to predict the hygroscopicity parameter $\kappa$ from the chemical composition of size-segregated particle samples.

The number of analyzed ions in this study is up to eight. The mass fractions of these ions vary as well as the hygroscopicity of inorganic compounds that are combined by these ions. Thus the contributions of individual inorganic ionic species to $\kappa$ are different. Besides, WSOC contributes to the hygroscopicity of particles. In Table 4 the correlation coefficients and slopes of the regression lines between $\kappa$ values and the mass fractions of individual ions as well as that of WSOC are listed. $\mathrm{NH}_{4}{ }^{+}, \mathrm{NO}_{3}{ }^{-}$and $\mathrm{SO}_{4}{ }^{2-}$ are the most abundant inorganic ions in the ambient particles and the mass fractions of these three ions are highly correlated with $\kappa$ values. For other inorganic ions $\left(\mathrm{Ca}^{2+}, \mathrm{Na}^{+}, \mathrm{K}^{+}, \mathrm{Mg}^{2+}, \mathrm{Cl}^{-}\right)$, no correlations between $\kappa$ values and their mass fractions are observed. For WSOC, there is no significant correlation between $\kappa$ values and its mass fractions as the regression coefficient $\left(R^{2}\right)$ is close to zero (Fig. 8). However, for particles smaller than $100 \mathrm{~nm}$, significant correlations between $\kappa$ values and the mass fractions of WSOC exist with the correlation coefficient up to 0.590 (Fig. 8). This can be explained by the substantial contribution of WSOC to the hygroscopicity of ultrafine particles during the HaChi summer campaign. For larger particles, inorganic compounds dominate and the contribution of WSOC decreases. The more abundant a species, the higher correlation is between $\kappa$ values and its mass fractions.

Here, a new linear regression parameterization of $\kappa$ values is proposed. $\mathrm{NH}_{4}{ }^{+}, \mathrm{NO}_{3}{ }^{-}$and $\mathrm{SO}_{4}{ }^{2-}$ are highly correlated with $\kappa$ values while other inorganic ions show no significant correlations with $\kappa$. WSOC is highly correlated with $\kappa$ for particles with diameters smaller than $100 \mathrm{~nm}$. So $\mathrm{NH}_{4}{ }^{+}$, $\mathrm{NO}_{3}{ }^{-}, \mathrm{SO}_{4}{ }^{2-}$ and WSOC are involved in the parameterization scheme. The mass fractions of the above four particle components are set as the independent variables and $\kappa$ is the dependent variable, then a multicomponent linear regression

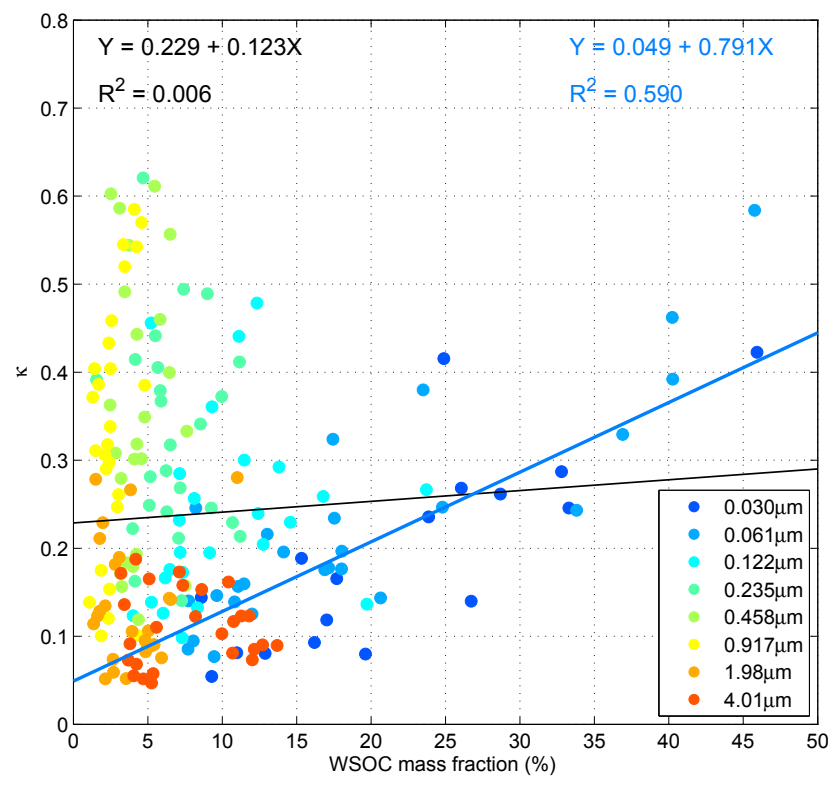

Fig. 8. The correlation between $\kappa$ and the mass fraction of WSOC. Dots with the same color represent particles from the same stage. Black line shows the correlation between $\kappa$ and the mass fraction of WSOC for particles from all stages, while blue line shows the correlation for particles smaller than $100 \mathrm{~nm}$. Corresponding statistic results are displayed in the top left and top right corners.

relationship is established based on the least square method:

$\kappa_{\text {reg }}=0.01+0.63 f_{\mathrm{NH}_{4}}+0.51 f_{\mathrm{NO}_{3}}+0.81 f_{\mathrm{SO}_{4}}+0.18 f_{\mathrm{WSOC}}$

where $\kappa_{\text {reg }}$ represents $\kappa$ calculated from the parameterization function and $F_{x}$ represents mass fraction of species $X$. For each group of chemical information, $\kappa$ can be evaluated through the iterative algorithm; meanwhile $\kappa_{\text {reg }}$ can be evaluated through the regression method shown above. The data sets of $\kappa$ values and $\kappa_{\text {reg values agree quite well }}$ (Fig. 9): $73.9 \%$ of data points are within the range of $30 \%$ deviation. For less hygroscopic particles, the calculated $\kappa_{\text {reg }}$ value based on the parameterization is slightly higher than the corresponding chemistry-derived $\kappa$ values.

Data sets from former studies are involved here to test the generality of this parameterization scheme. A comprehensive aerosol field campaign was conducted at a regional/coastal site in the Pearl River delta (PRD) in 2004 reporting chemical and hygroscopic properties of aerosols (Liu et al., 2008; Eichler et al., 2008), whereas the CCN activation behavior of particles as well as their chemical composition measured by an AMS was reported in a further campaign in 2006 (Rose et al., 2010, 2011). Another comprehensive campaign was conducted at a suburban site near Beijing in 2006, reporting the CCN activation behavior from fresh and aged air pollution and the corresponding chemical composition (Gunthe et al., 2011). It is important to note that in the studies listed above, the concentration of OC was reported, but WSOC was not. In this study, a WSOC fraction on OC of $50 \%$ is chosen 


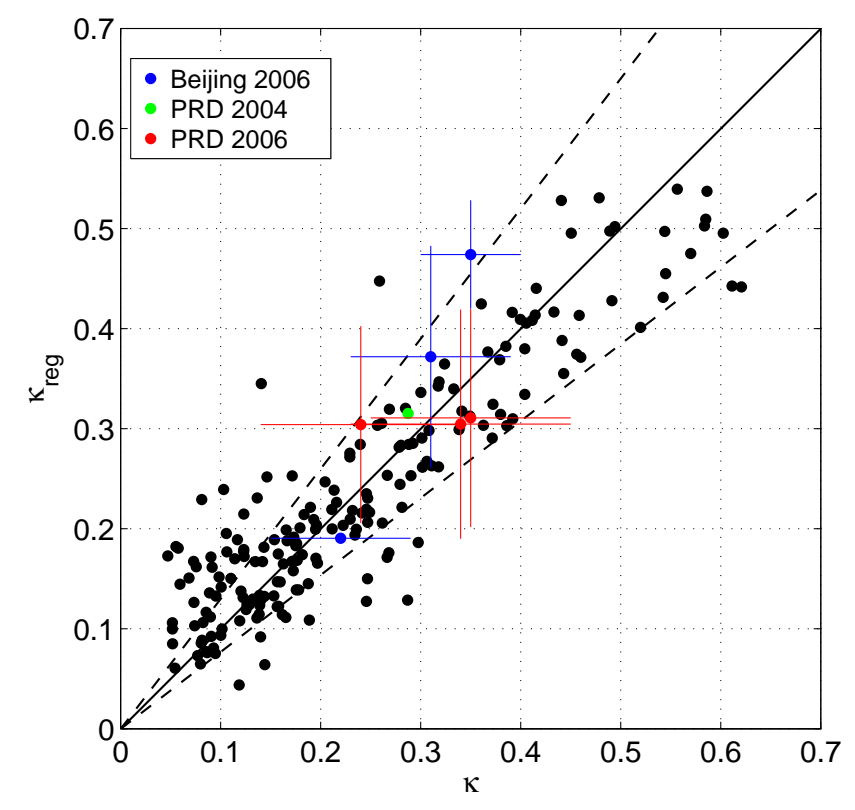

Fig. 9. The comparison of $\kappa_{\text {reg }}$ predicted from the parameterization scheme (ordinate) and $\kappa$ derived from chemical composition (abscissa). Values of $\kappa$ from former studies, predicted from the parameterization scheme (ordinate) and derived from GF or CCN activation (abscissa), are displayed in colored points. Solid line is $1: 1$ line and dashed lines indicate $30 \%$ deviation from the $1: 1$ line.

referring to the study of Eichler et al. (2008). Values of $\kappa_{\text {reg }}$ are predicted from the particle's chemical composition and the results are plotted in Fig. 9 as colored dots and error bars. The agreement between the parameterization-predicted $\kappa_{\text {reg }}$ values and the HGF- or CCN-derived $\kappa$ values is within $30 \%$ for most of the results except one. This indicates that the parameterization of hygroscopicity proposed in this study is applicable to a wide spread of measurements in urban and suburban areas in China.

\section{Summary and conclusions}

A comprehensive aerosol field campaign was conducted at a suburban site in the NCP in summer 2009. In this study, aerosol hygroscopic properties were investigated based on the particle's chemical composition analyzed from ambient aerosol samples, which were collected with a ten-stage BLPI twice a day. An HH-TDMA instrument was employed to measure HGFs of particles with dry diameters of 50,100, 200 and $250 \mathrm{~nm}$ at high RH conditions (90, 95 and $98.5 \%$ ), respectively. Furthermore, a parameterization scheme for hygroscopicity parameter $\kappa$ was developed based on high correlations between $\kappa$ values and several particle components such as $\mathrm{SO}_{4}{ }^{2-}, \mathrm{NO}_{3}{ }^{-}, \mathrm{NH}_{4}{ }^{+}$and WSOC.

The campaign average mass size distribution followed a unimodal pattern with its peak around $450 \mathrm{~nm}$. The average mass concentration for particles of all measured size ranges was $112.2 \mu \mathrm{g} \mathrm{m}^{-3}$. $\mathrm{SO}_{4}{ }^{2-}, \mathrm{NO}_{3}{ }^{-}$and $\mathrm{NH}_{4}{ }^{+}$were the three major inorganic ions and their mass concentrations were $20.4,14.6$ and $7.3 \mu \mathrm{g} \mathrm{m}^{-3}$, respectively. The average mass concentration of WSOC was $5.4 \mu \mathrm{g} \mathrm{m}^{-3}$. The shape of the particulate mass size distribution and the mass concentrations of the main particle components agreed well with former results reported by van Pinxteren et al. (2009). Almost half the particles between $150 \mathrm{~nm}$ and $1 \mu \mathrm{m}$ were composed of inorganics, and $\mathrm{SO}_{4}{ }^{2-}, \mathrm{NO}_{3}{ }^{-}$and $\mathrm{NH}_{4}{ }^{+}$together made up more than $90 \%$ of the inorganic mass concentration, whereas the rest of inorganic ions were relatively sparse in the ambient particles. For ultrafine particles, inorganic ions were less abundant than for larger particles, but OM was of particular importance for the ultrafine particles. For particles of around $30 \mathrm{~nm} \mathrm{OM}$ accounted for $77.3 \%$ of the total mass concentration, while the mass fraction of ions was only $18.6 \%$. The unbalance between weighed particulate mass concentration and the sum of all chemically analyzed particle components was especially pronounced for coarse particles, due to the unidentified insoluble mineral dust as well as the remnant of liquid water.

Petters and Kreidenweis (2007) proposed the $\kappa$-Köhler theory, where $\kappa$ represents the hygroscopicity of particles. For multicomponent particles, $\kappa$ is predicted by weighting the $\kappa$ values of individual particle components by its volume fraction, as the ZSR mixing rule indicates. In this study, aerosol particles were weighed under controlled conditions with the $\mathrm{RH}$ of $52 \%$ and the temperature of $20^{\circ} \mathrm{C}$. In order to be adapted for the ZSR mixing rule, the amount of condensed water had to be estimated and subtracted from the weighed aerosol mass concentration. Thus, an iterative algorithm was developed to estimate the liquid water amount and to evaluate the $\kappa$ value from the particle's chemical compositions. The campaign-average $\kappa$ distribution showed three distinct modes: a highly hygroscopic mode, a less hygroscopic mode and a nearly hydrophobic mode. The highly hygroscopic mode ranged from $150 \mathrm{~nm}$ to $1 \mu \mathrm{m}$ with the average $\kappa$ value greater than 0.3 . Particles in the less hygroscopic mode were smaller than $150 \mathrm{~nm}$ with the average $\kappa$ value slightly above 0.2 . Particles in the nearly hydrophobic mode were larger than $1 \mu \mathrm{m}$ with the average $\kappa$ value greater than 0.1 . Particles around $450 \mathrm{~nm}$ were the most hygroscopic with $\kappa$ values of 0.35 . Inorganic compounds contributed most to the observed hygroscopicity. Four major inorganic compounds $\left(\mathrm{NH}_{4} \mathrm{NO}_{3}, \mathrm{H}_{2} \mathrm{SO}_{4}, \mathrm{NH}_{4} \mathrm{HSO}_{4}\right.$ and $\left.\left(\mathrm{NH}_{4}\right)_{2} \mathrm{SO}_{4}\right)$ accounted for nearly $90 \%$ of the $\kappa$ value for particles in the highly hygroscopic mode. However, the contribution of WSOC to the particle hygroscopicity was significant for ultrafine particles. For particles of around $30 \mathrm{~nm}$, the contribution of WSOC was up to $52.2 \%$, surpassing that of inorganics. So the hygroscopicity of particles smaller than $150 \mathrm{~nm}$ would be underestimated without taking WSOC into account. The difference of less than $20 \%$ between chemistry-derived $\kappa$ values and HGF-derived values confirmed the good quality of chemistry-derived $\kappa$. 
Aerosol hygroscopicity is related to synoptic transport patterns and source regions. During the southerly pattern, when southerly wind dominated, air mass reached the campaign site after advecting over the highly industrialized areas with dense population and particles were more hygroscopic. While under the northerly pattern, when northerly wind dominated, air mass advected over relatively clean areas and particles were less hygroscopic. Aerosol hygroscopicity also showed diurnal variations. Aerosol particles were about $10 \%$ more hygroscopic during daytime than during nighttime. This corresponded to the differences of mass concentrations of inorganics between daytime and nighttime. The diurnal evolution of the PBL, the photochemical aging process and the enhanced EC emissions at night were suggested as explanations.

Mass fractions of $\mathrm{NH}_{4}{ }^{+}, \mathrm{NO}_{3}{ }^{-}$and $\mathrm{SO}_{4}{ }^{2-}$ were highly correlated with the $\kappa$ values, while other inorganic ions were scarcely correlated with the $\kappa$ values. WSOC and $\kappa$ values were highly correlated only for particles smaller than $100 \mathrm{~nm}$. Thus, a parameterization scheme for $\kappa$ values was developed using the mass fractions of $\mathrm{SO}_{4}{ }^{2-}, \mathrm{NO}_{3}{ }^{-}, \mathrm{NH}_{4}{ }^{+}$ and WSOC due to their high correlations with the $\kappa$ values. The results showed that the predicted $\kappa_{\text {reg }}$ values from the parameterization scheme agreed well with those derived by the iterative scheme and $73.9 \%$ of data points were within the range of $30 \%$ deviation. Chemical composition and hygroscopic parameters reported from other studies were involved in this scheme. All but one point were within the range of $30 \%$ deviation, indicating the quality and generality of the parameterization scheme.

Acknowledgements. This work is supported by the National 973 Program of China (2011CB403402), National Natural Science Foundation of China (41375134) and Beijing Natural Science Foundation (8131003).

Edited by: D. Covert

\section{References}

Achtert, P., Birmili, W., Nowak, A., Wehner, B., Wiedensohler, A., Takegawa, N., Kondo, Y., Miyazaki, Y., Hu, M., and Zhu, T.: Hygroscopic growth of tropospheric particle number size distributions over the North China Plain, J. Geophys. Res.-Atmos., 114, D00G07, doi:10.1029/2008JD010921, 2009.

Asa-Awuku, A., Nenes, A., Gao, S., Flagan, R. C., and Seinfeld, J. H.: Water-soluble SOA from Alkene ozonolysis: composition and droplet activation kinetics inferences from analysis of $\mathrm{CCN}$ activity, Atmos. Chem. Phys., 10, 1585-1597, doi:10.5194/acp10-1585-2010, 2010.
Asa-Awuku, A., Moore, R. H., Nenes, A., Bahreini, R., Holloway, J. S., Brock, C. A., Middlebrook, A. M., Ryerson, T. B., Jimenez, J. L., DeCarlo, P. F., Hecobian, A., Weber, R. J., Stickel, R., Tanner, D. J., and Huey, L. G.: Airborne cloud condensation nuclei measurements during the 2006 Texas Air Quality Study, J. Geophys. Res.-Atmos., 116, D11201, doi:10.1029/2010JD014874, 2011.

Chang, M. C., Sioutas, C., Kim, S., Gong, H., and Linn, W. S.: Reduction of nitrate losses from filter and impactor samplers by means of concentration enrichment, Atmos. Environ., 34, 85-98, 2000.

Chen, J., Zhao, C. S., Ma, N., Liu, P. F., Göbel, T., Hallbauer, E., Deng, Z. Z., Ran, L., Xu, W. Y., Liang, Z., Liu, H. J., Yan, P., Zhou, X. J., and Wiedensohler, A.: A parameterization of low visibilities for hazy days in the North China Plain, Atmos. Chem. Phys., 12, 4935-4950, doi:10.5194/acp-12-4935-2012, 2012

Cheng, Y. F., Zhang, Y. H., Hu, M., and Wiedensohler, A.: Observation-based method for investigating the atmospheric aerosol radiative properties in pearl river delta of China, Science Press, Beijing, 2008.

Clegg, S. L., Brimblecombe, P., and Wexler, A. S.: Thermodynamic model of the system $\mathrm{H}+-\mathrm{NH}_{4}^{+}-\mathrm{Na}^{+}-\mathrm{SO}_{4}{ }^{2-}-\mathrm{NB}_{3}{ }^{-}-\mathrm{Cl}^{-}-\mathrm{H}_{2} \mathrm{O}$ at 298.15 K, J. Phys. Chem. A, 102, 2155-2171, 1998.

Dusek, U., Frank, G. P., Curtius, J., Drewnick, F., Schneider, J., Kuerten, A., Rose, D., Andreae, M. O., Borrmann, S., and Poeschl, U.: Enhanced organic mass fraction and decreased hygroscopicity of cloud condensation nuclei (CCN) during new particle formation events, Geophys. Res. Lett., 37, L03804, doi:10.1029/2009GL040930, 2010.

Eichler, H., Cheng, Y. F., Birmili, W., Nowak, A., Wiedensohler, A., Brueggemann, E., Gnauk, T., Herrmann, H., Althausen, D., Ansmann, A., Engelmann, R., Tesche, M., Wendisch, M., Zhang, Y. H., Hu, M., Liu, S., and Zeng, L. M.: Hygroscopic properties and extinction of aerosol particles at ambient relative humidity in South-Eastern China, Atmos. Environ., 42, 6321-6334, 2008.

Fountoukis, C. and Nenes, A.: ISORROPIA II: a computationally efficient thermodynamic equilibrium model for $\mathrm{K}^{+}$. $\mathrm{Ca}^{2+}-\mathrm{Mg}^{2+}-\mathrm{NH}_{4}{ }^{+}-\mathrm{Na}^{+}-\mathrm{SO}_{4}{ }^{2}-\mathrm{NO}_{3}{ }^{-}-\mathrm{Cl}^{-}-\mathrm{H}_{2} \mathrm{O}$ aerosols, Atmos. Chem. Phys., 7, 4639-4659, doi:10.5194/acp-7-4639-2007, 2007.

Gunthe, S. S., King, S. M., Rose, D., Chen, Q., Roldin, P., Farmer, D. K., Jimenez, J. L., Artaxo, P., Andreae, M. O., Martin, S. T., and Pöschl, U.: Cloud condensation nuclei in pristine tropical rainforest air of Amazonia: size-resolved measurements and modeling of atmospheric aerosol composition and CCN activity, Atmos. Chem. Phys., 9, 7551-7575, doi:10.5194/acp-9-75512009, 2009.

Gunthe, S. S., Rose, D., Su, H., Garland, R. M., Achtert, P., Nowak, A., Wiedensohler, A., Kuwata, M., Takegawa, N., Kondo, Y., Hu, M., Shao, M., Zhu, T., Andreae, M. O., and Pöschl, U.: Cloud condensation nuclei $(\mathrm{CCN})$ from fresh and aged air pollution in the megacity region of Beijing, Atmos. Chem. Phys., 11, 11023 11039, doi:10.5194/acp-11-11023-2011, 2011.

Gysel, M., Weingartner, E., Nyeki, S., Paulsen, D., Baltensperger, U., Galambos, I., and Kiss, G.: Hygroscopic properties of watersoluble matter and humic-like organics in atmospheric fine aerosol, Atmos. Chem. Phys., 4, 35-50, doi:10.5194/acp-4-352004, 2004. 
Gysel, M., Crosier, J., Topping, D. O., Whitehead, J. D., Bower, K. N., Cubison, M. J., Williams, P. I., Flynn, M. J., McFiggans, G. B., and Coe, H.: Closure study between chemical composition and hygroscopic growth of aerosol particles during TORCH2, Atmos. Chem. Phys., 7, 6131-6144, doi:10.5194/acp-7-61312007, 2007.

Hennig, T., Massling, A., Brechtel, F. J., and Wiedensohler, A.: A tandem DMA for highly temperature-stabilized hygroscopic particle growth measurements between $90 \%$ and $98 \%$ relative humidity, J. Aerosol Sci., 36, 1210-1223, 2005.

Hillamo, R. E. and Kauppinen, E. I.: On the Performance of the Berner Low-Pressure Impactor, Aerosol Sci. Technol., 14, $33-$ 47, 1991.

IPCC: Climate Change 2007 - The Physical Science Basis, Cambridge University Press, New York, 2007.

Jayne, J. T., Leard, D. C., Zhang, X. F., Davidovits, P., Smith, K. A., Kolb, C. E., and Worsnop, D. R.: Development of an aerosol mass spectrometer for size and composition analysis of submicron particles, Aerosol Sci. Technol., 33, 49-70, 2000.

Junge, C. and McLaren, E.: Relationship Of Cloud Nuclei Spectra To Aerosol Size Distribution And Composition, J. Atmos. Sci., 28, 382-390, doi:10.1175/15200469(1971)028<0382:ROCNST>2.0.CO;2, 1971.

Laaksonen, A., Korhonen, P., Kulmala, M., and Charlson, R. J.: Modification of the Kuhler equation to include soluble trace gases and slightly soluble substances, J. Atmos. Sci., 55, 853862, 1998.

Liu, P. F., Zhao, C. S., Zhang, Q., Deng, Z. Z., Huang, M. Y., Ma, X. C., and Tie, X. X.: Aircraft study of aerosol vertical distributions over Beijing and their optical properties, Tellus Ser. BChem. Phys. Meteorol., 61, 756-767, 2009.

Liu, P. F., Zhao, C. S., Göbel, T., Hallbauer, E., Nowak, A., Ran, L., Xu, W. Y., Deng, Z. Z., Ma, N., Mildenberger, K., Henning, S., Stratmann, F., and Wiedensohler, A.: Hygroscopic properties of aerosol particles at high relative humidity and their diurnal variations in the North China Plain, Atmos. Chem. Phys., 11, 3479-3494, doi:10.5194/acp-11-3479-2011, 2011.

Liu, S., Hu, M., Slanina, S., He, L.-Y., Niu, Y.-W., Bruegemann, E., Gnauk, T., and Herrmann, H.: Size distribution and source analysis of ionic compositions of aerosols in polluted periods at Xinken in Pearl River Delta (PRD) of China, Atmos. Environ., 42, 6284-6295, 2008.

Ma, N., Zhao, C. S., Nowak, A., Müller, T., Pfeifer, S., Cheng, Y. F., Deng, Z. Z., Liu, P. F., Xu, W. Y., Ran, L., Yan, P., Göbel, T., Hallbauer, E., Mildenberger, K., Henning, S., Yu, J., Chen, L. L., Zhou, X. J., Stratmann, F., and Wiedensohler, A.: Aerosol optical properties in the North China Plain during HaChi campaign: an in-situ optical closure study, Atmos. Chem. Phys., 11, 5959-5973, doi:10.5194/acp-11-5959-2011, 2011.

Ma, N., Zhao, C. S., Müller, T., Cheng, Y. F., Liu, P. F., Deng, Z. Z., Xu, W. Y., Ran, L., Nekat, B., van Pinxteren, D., Gnauk, T., Müller, K., Herrmann, H., Yan, P., Zhou, X. J., and Wiedensohler, A.: A new method to determine the mixing state of light absorbing carbonaceous using the measured aerosol optical properties and number size distributions, Atmos. Chem. Phys., 12, 23812397, doi:10.5194/acp-12-2381-2012, 2012.
Mader, B. T., Yu, J. Z., Xu, J. H., Li, Q. F., Wu, W. S., Flagan, R. C., and Seinfeld, J. H.: Molecular composition of the water-soluble fraction of atmospheric carbonaceous aerosols collected during ACE-Asia, J. Geophys. Res.-Atmos., 109, D06206, doi:10.1029/2003JD004105, 2004.

Massling, A., Stock, M., Wehner, B., Wu, Z. J., Hu, M., Bruggemann, E., Gnauk, T., Herrmann, H., and Wiedensohler, A.: Size segregated water uptake of the urban submicrometer aerosol in Beijing, Atmos. Environ., 43, 1578-1589, 2009.

Meier, J., Wehner, B., Massling, A., Birmili, W., Nowak, A., Gnauk, T., Brüggemann, E., Herrmann, H., Min, H., and Wiedensohler, A.: Hygroscopic growth of urban aerosol particles in Beijing (China) during wintertime: a comparison of three experimental methods, Atmos. Chem. Phys., 9, 6865-6880, doi:10.5194/acp9-6865-2009, 2009.

Morino, Y., Kondo, Y., Takegawa, N., Miyazaki, Y., Kita, K., Komazaki, Y., Fukuda, M., Miyakawa, T., Moteki, N., and Worsnop, D. R.: Partitioning of $\mathrm{HNO}_{3}$ and particulate nitrate over Tokyo: Effect of vertical mixing, J. Geophys. Res.-Atmos., 111, D15215, doi:10.1029/2005JD006887, 2006.

Padro, L. T., Tkacik, D., Lathem, T., Hennigan, C. J., Sullivan, A. P., Weber, R. J., Huey, L. G., and Nenes, A.: Investigation of cloud condensation nuclei properties and droplet growth kinetics of the water-soluble aerosol fraction in Mexico City, J. Geophys. Res.-Atmos., 115, D09204, doi:10.1029/2009JD013195, 2010.

Pan, X. L., Yan, P., Tang, J., Ma, J. Z., Wang, Z. F., Gbaguidi, A., and Sun, Y. L.: Observational study of influence of aerosol hygroscopic growth on scattering coefficient over rural area near Beijing mega-city, Atmos. Chem. Phys., 9, 7519-7530, doi:10.5194/acp-9-7519-2009, 2009.

Petters, M. D. and Kreidenweis, S. M.: A single parameter representation of hygroscopic growth and cloud condensation nucleus activity, Atmos. Chem. Phys., 7, 1961-1971, doi:10.5194/acp-71961-2007, 2007.

Petters, M. D., Wex, H., Carrico, C. M., Hallbauer, E., Massling, A., McMeeking, G. R., Poulain, L., Wu, Z., Kreidenweis, S. M., and Stratmann, F.: Towards closing the gap between hygroscopic growth and activation for secondary organic aerosol - Part 2: Theoretical approaches, Atmos. Chem. Phys., 9, 3999-4009, doi:10.5194/acp-9-3999-2009, 2009.

Quan, J., Zhang, Q., He, H., Liu, J., Huang, M., and Jin, H.: Analysis of the formation of fog and haze in North China Plain (NCP), Atmos. Chem. Phys., 11, 8205-8214, doi:10.5194/acp-11-82052011, 2011.

Ran, L., Zhao, C. S., Xu, W. Y., Lu, X. Q., Han, M., Lin, W. L., Yan, P., Xu, X. B., Deng, Z. Z., Ma, N., Liu, P. F., Yu, J., Liang, W. D., and Chen, L. L.: VOC reactivity and its effect on ozone production during the HaChi summer campaign, Atmos. Chem. Phys., 11, 4657-4667, doi:10.5194/acp-11-4657-2011, 2011.

Rissler, J., Vestin, A., Swietlicki, E., Fisch, G., Zhou, J., Artaxo, P., and Andreae, M. O.: Size distribution and hygroscopic properties of aerosol particles from dry-season biomass burning in Amazonia, Atmos. Chem. Phys., 6, 471-491, doi:10.5194/acp6-471-2006, 2006. 
Rose, D., Nowak, A., Achtert, P., Wiedensohler, A., Hu, M., Shao, M., Zhang, Y., Andreae, M. O., and Pöschl, U.: Cloud condensation nuclei in polluted air and biomass burning smoke near the mega-city Guangzhou, China - Part 1: Size-resolved measurements and implications for the modeling of aerosol particle hygroscopicity and CCN activity, Atmos. Chem. Phys., 10, 33653383, doi:10.5194/acp-10-3365-2010, 2010.

Rose, D., Gunthe, S. S., Su, H., Garland, R. M., Yang, H., Berghof, M., Cheng, Y. F., Wehner, B., Achtert, P., Nowak, A., Wiedensohler, A., Takegawa, N., Kondo, Y., Hu, M., Zhang, Y., Andreae, M. O., and Pöschl, U.: Cloud condensation nuclei in polluted air and biomass burning smoke near the mega-city Guangzhou, China - Part 2: Size-resolved aerosol chemical composition, diurnal cycles, and externally mixed weakly $\mathrm{CCN}$-active soot particles, Atmos. Chem. Phys., 11, 2817-2836, doi:10.5194/acp-112817-2011, 2011.

Saxena, P., Hildemann, L. M., McMurry, P. H., and Seinfeld, J. H.: Organics Alter Hygroscopic Behavior Of Atmospheric Particles, J. Geophys. Res.-Atmos., 100, 18755-18770, 1995.

Seinfeld, J. H. and Pandis, S. N.: Atmospheric chemistry and physics : from air pollution to climate change, Wiley, New York, xxvii, 1326 pp., 1998.

Shulman, M. L., Jacobson, M. C., Carlson, R. J., Synovec, R. E., and Young, T. E.: Dissolution behavior and surface tension effects of organic compounds in nucleating cloud droplets, Geophys. Res. Lett., 23, 277-280, 1996.

Stokes, R. H. and Robinson, R. A.: Interactions in Aqueous Nonelectrolyte Solutions .I. Solute-Solvent Equilibria, J. Phys. Chem., 70, 2126-2131, doi:10.1021/j100879a010, 1966.

Swietlicki, E., Hansson, H. C., Hameri, K., Svenningsson, B., Massling, A., McFiggans, G., McMurry, P. H., Petaja, T., Tunved, P., Gysel, M., Topping, D., Weingartner, E., Baltensperger, U., Rissler, J., Wiedensohler, A., and Kulmala, M.: Hygroscopic properties of submicrometer atmospheric aerosol particles measured with H-TDMA instruments in various environments - a review, Tellus Ser. B-Chem. Phys. Meteorol., 60, 432-469, 2008.

Turpin, B. J. and Lim, H. J.: Species contributions to PM2.5 mass concentrations: Revisiting common assumptions for estimating organic mass, Aerosol Sci. Technol., 35, 602-610, 2001.

van Pinxteren, D., Bruggemann, E., Gnauk, T., Iinuma, Y., Muller, K., Nowak, A., Achtert, P., Wiedensohler, A., and Herrmann, H.: Size- and time-resolved chemical particle characterization during CAREBeijing-2006: Different pollution regimes and diurnal profiles, J. Geophys. Res.-Atmos., 114, D00G09, doi:10.1029/2008JD010890, 2009.
Wex, H., Petters, M. D., Carrico, C. M., Hallbauer, E., Massling, A., McMeeking, G. R., Poulain, L., Wu, Z., Kreidenweis, S. M., and Stratmann, F.: Towards closing the gap between hygroscopic growth and activation for secondary organic aerosol: Part $1-$ Evidence from measurements, Atmos. Chem. Phys., 9, 3987-3997, doi:10.5194/acp-9-3987-2009, 2009.

Wiedensohler, A., Cheng, Y. F., Nowak, A., Wehner, B., Achtert, P., Berghof, M., Birmili, W., Wu, Z. J., Hu, M., Zhu, T., Takegawa, N., Kita, K., Kondo, Y., Lou, S. R., Hofzumahaus, A., Holland, F., Wahner, A., Gunthe, S. S., Rose, D., Su, H., and Poeschl, U.: Rapid aerosol particle growth and increase of cloud condensation nucleus activity by secondary aerosol formation and condensation: A case study for regional air pollution in northeastern China, J. Geophys. Res.-Atmos., 114, D00G08, doi:10.1029/2008JD010884, 2009.

Xing, L., Fu, T.-M., Cao, J. J., Lee, S. C., Wang, G. H., Ho, K. F., Cheng, M.-C., You, C.-F., and Wang, T. J.: Seasonal and spatial variability of the $\mathrm{OM} / \mathrm{OC}$ mass ratios and high regional correlation between oxalic acid and zinc in Chinese urban organic aerosols, Atmos. Chem. Phys., 13, 4307-4318, doi:10.5194/acp13-4307-2013, 2013

Xu, W. Y., Zhao, C. S., Ran, L., Deng, Z. Z., Liu, P. F., Ma, N., Lin, W. L., Xu, X. B., Yan, P., He, X., Yu, J., Liang, W. D., and Chen, L. L.: Characteristics of pollutants and their correlation to meteorological conditions at a suburban site in the North China Plain, Atmos. Chem. Phys., 11, 4353-4369, doi:10.5194/acp-114353-2011, 2011

Yan, P., Pan, X. L., Tang, J., Zhou, X. J., Zhang, R. J., and Zeng, L. M.: Hygroscopic growth of aerosol scattering coefficient: A comparative analysis between urban and suburban sites at winter in Beijing, Particuology, 7, 52-60, 2009.

Zdanovskii, A. B.: Novyi Metod Rascheta Rastvorimostei Elektrolitov V Mnogokomponentnykh Sistemakh .1, Zhurnal Fizicheskoi Khimii, 22, 1478-1485, 1948.

Zhao, C., Tie, X., Brasseur, G., Noone, K. J., Nakajima, T., Zhang, Q., Zhang, R., Huang, M., Duan, Y., Li, G., and Ishizaka, Y.: Aircraft measurements of cloud droplet spectral dispersion and implications for indirect aerosol radiative forcing, Geophys. Res. Lett., 33, L16809, doi:10.1029/2006GL026653, 2006a.

Zhao, C. S., Tie, X. X., and Lin, Y. P.: A possible positive feedback of reduction of precipitation and increase in aerosols over eastern central China, Geophys. Res. Lett., 33, L11814, doi:10.1029/2006GL025959, 2006b. 